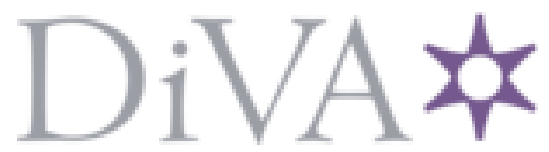

http://www.diva-portal.org

This is the published version of a paper published in Biological Invasions.

Citation for the original published paper (version of record):

Holopainen, R., Lehtiniemi, M., Meier, H E., Albertsson, J., Gorokhova, E. et al. (2016) Impacts of changing climate on the non-indigenous invertebrates in the northern Baltic Sea by end of the twenty-first century.

Biological Invasions, 18(10): 3015-3032

http://dx.doi.org/10.1007/s10530-016-1197-z

Access to the published version may require subscription.

N.B. When citing this work, cite the original published paper.

Permanent link to this version:

http://urn.kb.se/resolve?urn=urn:nbn:se:umu:diva-126291 


\title{
Impacts of changing climate on the non-indigenous invertebrates in the northern Baltic Sea by end of the twenty-first century
}

\author{
Reetta Holopainen • Maiju Lehtiniemi • H. E. Markus Meier • \\ Jan Albertsson · Elena Gorokhova · Jonne Kotta • \\ Markku Viitasalo
}

Received: 18 September 2014/ Accepted: 7 June 2016/Published online: 17 June 2016

(C) The Author(s) 2016. This article is published with open access at Springerlink.com

\begin{abstract}
Biological invasions coupled with climate change drive changes in marine biodiversity. Warming climate and changes in hydrology may either enable or hinder the spread of non-indigenous species (NIS) and little is known about how climate change modifies the richness and impacts of NIS in specific sea areas. We calculated from climate change simulations (RCO-SCOBI model) the changes in summer time conditions which northern Baltic Sea may to go through by the end of the twenty-first century, e.g., $2-5{ }^{\circ} \mathrm{C}$ sea surface temperature rise and even up to 1.75 unit decrease in salinity. We reviewed the temperature and salinity tolerances (i.e., physiological tolerances and occurrence ranges in the field) of pelagic and benthic NIS established in-or with dispersal potential to- the northern Baltic Sea, and
\end{abstract}

Electronic supplementary material The online version of this article (doi:10.1007/s10530-016-1197-z) contains supplementary material, which is available to authorized users.

R. Holopainen $(\bowtie) \cdot$ M. Lehtiniemi · M. Viitasalo Marine Research Centre, Finnish Environment Institute (SYKE), P.O. Box 140, 00251 Helsinki, Finland e-mail: holopainenreetta@gmail.com

H. E. M. Meier

Leibniz Institute for Baltic Sea Research Warnemünde, 18119 Rostock, Germany

H. E. M. Meier

Swedish Meteorological and Hydrological Institute, 60176 Norrköping, Sweden assessed how climate change will likely affect them. Our findings suggest a future decrease in barnacle larvae and an increase in Ponto-Caspian cladocerans in the pelagic community. In benthos, polychaetes, gastropods and decapods may become less abundant. By contrast, dreissenid bivalves, amphipods and mysids are expected to widen their distribution and increase in abundance in the coastal areas of the northern Baltic Sea. Potential salinity decrease acts as a major driver for NIS biogeography in the northern Baltic Sea, but temperature increase and extended summer season allow higher reproduction success in bivalves, zooplankton, amphipods and mysids. Successful NIS, i.e., coastal crustacean and bivalve species, pose a risk to native biota, as many of them have already demonstrated harmful effects in the Baltic Sea.

\author{
J. Albertsson \\ Umeå Marine Sciences Centre, Umeå University, \\ 90571 Norrbyn, Hörnefors, Sweden \\ E. Gorokhova \\ Department of Environmental Science and Analytical \\ Chemistry, Stockholm University, 10691 Stockholm, \\ Sweden \\ J. Kotta \\ Estonian Marine Institute, University of Tartu, Mäealuse \\ 14, 12618 Tallinn, Estonia
}


Keywords Brackish water - Environmental tolerance $\cdot$ Climate change $\cdot$ Spionida $\cdot$ Mollusca . Arthropoda

\section{Introduction}

Biological invasions along with climate change have been recognized as a major threat and a direct driver for changes in marine biodiversity (Rockström et al. 2009; UNEP 2006). Both processes are able to cause major changes in the geographical range of native species and communities (Hampe and Petit 2005; Kernan 2015; Parmesan 2006; Walther et al. 2009). Also various direct consequences of the climate change for the invasive species (i.e. non-indigenous species or NIS, with negative impacts on biota, economic values, or human health) have been proposed (Hellmann et al. 2008), including for example changes to climatic constraints that control the distribution of non-indigenous species. Climate change may also change the way these species impact the environment and alter the effectiveness of management strategies aimed to mitigate the harmful impacts of invasive species. Majority of the available literature on climate-induced biological invasions deals with warming effects (Walther et al. 2009). Most often climate change has been considered to favour invasive species (Dukes and Mooney 1999; Thuiller et al. 2007), and globally a large-scale invasion of species from warm water environments to cold marine waters is expected (Jones and Cheung 2014). Climate change may for instance create new habitats for thermophilic non-indigenous species in areas where they previously would have not been able to survive and reproduce (Sorte et al. 2010; Walther et al. 2009). Other climatic factors should be however taken into more consideration, as especially in the northern latitudes the future climate projections suggest more precipitation, and hence more freshwater discharge to the sea (IPCC 2013). The reduced salinity in estuarine habitats has in some cases shown to be an even more important factor than temperature in governing the local distributions of species (Brady and Somero 2006a, b).

Bioinvasion studies under future climate deal mostly with the range expansion of a single or a few species (Gallardo and Aldridge 2013; McDowell et al. 2014). The direct consequences of climate change on multiple invasive or non-indigenous species have been studied very little. The Baltic Sea in the northern latitudes has been sometimes playfully called 'a field laboratory for invasion biology' (Leppäkoski et al. 2002), and as one of the best studied sea areas in the world, with relatively few indigenous species and with a high number of introduced species, is an ideal area for studying the impacts of climate change on nonindigenous species. As a brackish water body it also serves as a study area for changes in future hydrology, in addition to changes in temperature.

As many as 119 non-indigenous species have been observed in the Baltic Sea, where the coastal southern and northern lagoons and gulfs suffer from a high level of 'biopollution' (Zaiko et al. 2011). By non-indigenous species we refer to (not necessarily invasive) species, which would have not been able to disperse from their natural range to the Baltic Sea without some human vector, including for instance vectors like shipping or deliberate release in the wild. Majority of the NIS in the Baltic Sea are benthic or pelagic invertebrates (crustaceans, mollusks, annelids), with some fish, macrophyte and other species (Zaiko et al. 2011). Consequences of recent warming on some NIS in the northern Baltic Sea have been suggested. According to Ojaveer et al. (2011) zooplankton species Cercopagis pengoi, cirriped Amphibalanus improvisus and polychaetes Marenzelleria spp. have become more abundant in the Gulf of Finland and Gulf of Riga during recent decades and this has been partially accounted for mild winters and warmer summers. Panov et al. (2007) have suggested that non-indigenous zooplankton species have positively responded to changes in climatic conditions of the recent past, allowing these species to reproduce and establish in the Baltic Sea. However, no studies on the impacts of both temperature and salinity changes on multiple non-indigenous species, have been published for the Baltic Sea, although many native species have been assessed for future changes (Vuorinen et al. 2015).

Due to its small water volume $\left(21,205 \mathrm{~km}^{3}\right)$ and large watershed $\left(1,633,290 \mathrm{~km}^{2}\right)$ the semi-enclosed Baltic Sea is particularly vulnerable for climate induced changes in hydrology. Since its formation following the last glaciation, strong gradients have existed in the Baltic Sea for temperature, and salinity which decreases from ca. 20 PSU in the Danish straits to 1-2 PSU in the northern and eastern parts (Leppäranta and Myrberg 2009). In addition to spatial 
gradients, significant long-term variations in temperature and salinity occur. Large-scale atmospheric patterns affect the salinity inflow, water exchange with the North Atlantic and temperature variability (Leppäranta and Myrberg 2009). The Baltic Sea is expected to face considerable hydrographical (temperature and salinity) changes due to climate change during the twenty-first century. Projections of the Baltic Sea suggest an increase of the mean air temperature and precipitation between 1969-1998 and 2070-2099, by about $2.7-3.8{ }^{\circ} \mathrm{C}$ and $12-18 \%$ respectively (Meier et al. 2012).

The Baltic Sea has relatively low biodiversity, and temperature and salinity are the major environmental factors regulating the distribution of the biota (Ojaveer et al. 2010). Both indigenous and non-indigenous species face physiological challenges especially in the northern Baltic Sea, where temperature of sea water is relatively low even during summer, and salinity is critically low for marine species and high for freshwater species (Remane 1934). As the biota in this area hence seems sensitive to climate change, we used the northern Baltic Sea as a test area to qualitatively study, which NIS are likely to increase in abundance and expand their distribution range, and which on the other hand may withdraw from this area and become reduced in abundance. This way we address the key question raised by Hellmann et al. (2008) on whether or not climate change is a zero-sum game for invasive species, i.e. causing the emergence of new invasive species but also reducing the impacts of extant invasive species. This question remains to be fairly understudied in sea areas across the earth and here we address it in the northern Baltic Sea. In contrast to the original question we do not only consider invasive species but also some NIS, which are established but so far have not been considered very invasive.

Based on the state-of-art climate change projections for the Baltic Sea (Meier et al. 2012), we assessed how temperature and salinity will change during the summer season by end of the twenty-first century. Based on literature we assessed what consequences these changes might have on the invertebrate NIS, which are established in the northern Baltic Sea, or which have a dispersal potential from the southern Baltic Sea. Other factors than temperature and salinity were viewed not to affect the large scale predictions in a measurable way as they have a negligible effect on the species' current large-scale distributions and abundances. Some genetic and physiological adaptation to temperature and salinity within NIS is possible to occur during the twenty-first century, but we have no means of assessing it in the present paper and therefore adaptation is not taken into account. For this work, we reviewed from literature the basic physiological requirements-temperature and salinity-for multiple non-indigenous benthic crustaceans, mollusks, cirriped, polychaetes and pelagic zooplankton species. We report here how climate change may in the long run favour certain species, but also heavily reduce some other NIS in the northern Baltic Sea. Despite the differences in the species' background and in invasion history, all of the selected species are established and have already become naturalised in the Baltic Sea i.e. forming free-living, self-sustaining (reproducing) and durable populations.

\section{Materials and methods}

Hydrographic climate projections for summers during 2005-2009 and 2095-2099

Meier et al. (2012) have used a coupled physicalbiogeochemical model (RCO-SCOBI) to simulate the temperature, salinity, bottom oxygen, nutrient, phytoplankton and secchi depth changes in the Baltic Sea for 1961-2099. This state-of-art model, RCO-SCOBI, is forced by two regionalized global general circulation models (GCMs) driven by two IPCC emission scenarios (A1B and A2) (Nakicenovic et al. 2000). The model is coupled to a sea ice model and has its boundary with the Atlantic in the northern Kattegat. For further details of the RCO model and the atmospheric downscaling see Meier (2001, 2007), Meier and Kauker (2003), and Meier et al. (2011).

The spatial resolution of RCO-SCOBI model is 2 nautical miles and the original SMHI (Swedish Meteorological and Hydrological Institute) simulation data was imported to ArcMap 10.1 programme for further calculations. We calculated the summer means (JuneAugust) for temperature and salinity in present (years 2005-2009) and future conditions (years 2095-2099). We used all the four available emission scenario simulations (three ECHAM5 and one HadCM3, Table 1) to calculate the ensemble summer means from simulation-specific daily average values for the surface layer $(0-15 \mathrm{~m})$ and bottom layer (bottom $3 \mathrm{~m}$ ). 
The temperature and salinity in the Baltic Sea go through natural long-term variations and as we had chosen a relatively short (5-year) period to represent the current and future conditions, the statistical differences for present and future conditions needed to be tested so that we could say whether the calculated changes in temperature and salinity (from 2005-2009 to 2095-2099) are significant, or so small that they could fall within natural variability. Daily averages from the 5-year periods, from each data point (i.e., grid cell on a map), was tested as paired observations between present and future for each parameter (surface temperature, bottom temperature, surface salinity, bottom salinity). We used the non-parametric Wilcoxon signed rank test (for paired samples) as the modeled parameter values could not be normalized.

Meier et al. (2012) have carried out a model evaluation for temperature and salinity at deep water stations in the Baltic Sea but no model validation against coastal observations have been made previously. We validated temperature and salinity from the hind-cast model for the years 2005-2009 against four Finnish coastal intense monitoring stations (LAV-4, KYVY8A, Seili and Utö, Fig. 1). Based on this we decided to use equal weighting for each of the four simulations in our ensemble model as this way the results matched better with the field observations in coastal areas (data not shown). The differences between the equally weighted ensemble model (used in this study) and an ensemble model weighted similarly to Meier et al. (2012, weighting given in Table 1 but the results are not used in this study), were very small but the equal weighting worked better in coastal areas, giving greater emphasis for the three ECHAM5 simulations than to the one HadCM3 simulation.
Review on the non-indigenous species' temperature and salinity ranges

Extensive species lists and information on the NIS' origin and invasion history in the Baltic Sea can be found in e.g. Leppäkoski and Olenin (2000), Zaiko et al. (2011) and in AquaNIS database (Olenin et al. 2014). To evaluate the consequences of climate change for NIS, we reviewed the temperature and salinity ranges (i.e. physiological tolerances tested in laboratory, in situ measurements related to NIS observations and study area conditions in the basins where NIS have occurred) of twenty-four selected non-indigenous invertebrate species which are either present in the northern Baltic Sea (Gulf of Finland, Gulf of Riga, Gulf of Bothnia and northern Baltic Proper, Fig. 1) or established in the southern Baltic Sea gulfs and lagoons, and which are were considered to exhibit dispersal potential to North. The chosen species belong to the major groups of NIS in the Baltic Sea and are all established in the Baltic Sea and have become common in areas where they occur. Criterion for the selection of these species was that there exists enough information on their distribution and temperature and salinity ranges to assess the likely impacts of future changes. We focused the study on non-indigenous benthic crustaceans (amphipods and mysids), molluscs (dreissenid bivalves), cirripeds (barnacle), polychaetes (Marenzelleria spp.) and pelagic zooplankton (onychopod cladoceran) species (Table 2). Information on the distribution of these species, the field conditions (salinity and temperature) where NIS have been observed and their laboratory tested physiological tolerances, was sought mostly from peer reviewed literature, but also a few national reports

Table 1 The four climate change simulations available from Meier et al. (2012) and the weighting given for each simulation in this study to calculate the ensemble summer mean salinity and temperature for 2005-2009 and 2095-2099

\begin{tabular}{lll}
\hline Climate change simulation & $\begin{array}{l}\text { Weighting of simulations in } \\
\text { the present study }\end{array}$ & $\begin{array}{l}\text { Weighting of simulations in the study } \\
\text { by Meier et al. (2012) }\end{array}$ \\
\hline RCO-SCOBI-HadCM3-A1B_466 & $1 / 4$ & $1 / 2$ \\
RCO-SCOBI-ECHAM5-r3-A1B & $1 / 4$ & $1 / 6$ \\
RCO-SCOBI-ECHAM5-r1-A1B & $1 / 4$ & $1 / 6$ \\
RCO-SCOBI-ECHAM5-r1-A2 & $1 / 4$ & $1 / 6$ \\
\hline
\end{tabular}


Fig. 1 Sub-basins of the Baltic Sea and the four coastal monitoring stations (LAV-4, KYVY-8A, Seili \& Utö) used for evaluation of the RCO-SCOBI model performance in coastal areas

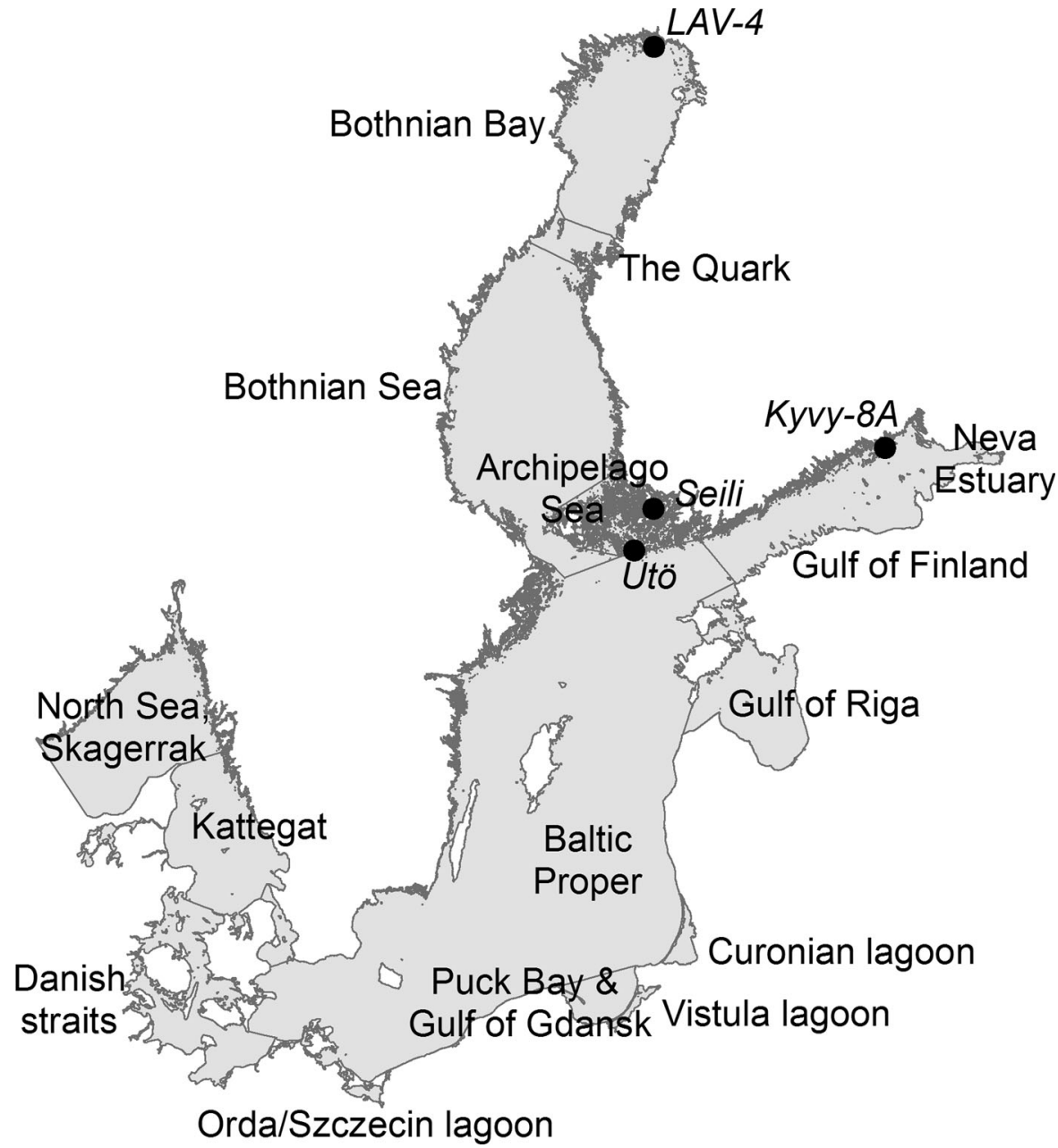

were available. We focused the literature review on temperature and salinity because these factors strongly influence species distribution in the Baltic Sea. Both of these environmental factors directly influence animal physiology (Somero 2012) and are relevant in the context of Baltic climate change.

\section{Results}

Hydrographic climate projections for summers during 2005-2009 and 2095-2099

The Wilcoxon signed rank test for salinity and temperature in surface and bottom layers showed statistical difference $(p<0.05)$ in pair-wise testing of present and future and conditions. Hence the salinity and temperature changes presented in this study are viewed to be due to anthropogenic climate change, and not caused by natural variability. In the climate projections the largest temperature changes between 2005-2009 and 2095-2099 in the Baltic Sea are expected to occur in the most northern parts of the Gulf of Bothnia and eastern parts of the Gulf of Finland. The surface temperature in the Bothnian Bay and eastern Gulf of Finland is projected to rise by $4-5{ }^{\circ} \mathrm{C}$ (Fig. 2a) with some even larger changes in some coastal areas (not shown due to resolution). In the Bothnian Sea temperature on the surface is projected to increase approximately by $3.5^{\circ} \mathrm{C}$ and in the Gulf of Finland and the Baltic Proper mostly by $3{ }^{\circ} \mathrm{C}$. The summer mean sea surface temperature $(0-15 \mathrm{~m})$ in the future may range from 12 to $23{ }^{\circ} \mathrm{C}$ in coastal areas. In the entire Baltic Sea the bottom temperature $(3 \mathrm{~m}$ from bottom) changes are highest along the eastern coasts of the basins, except in the Bothnian Sea, where the 
Table 2 Invertebrate NIS considered in the present study

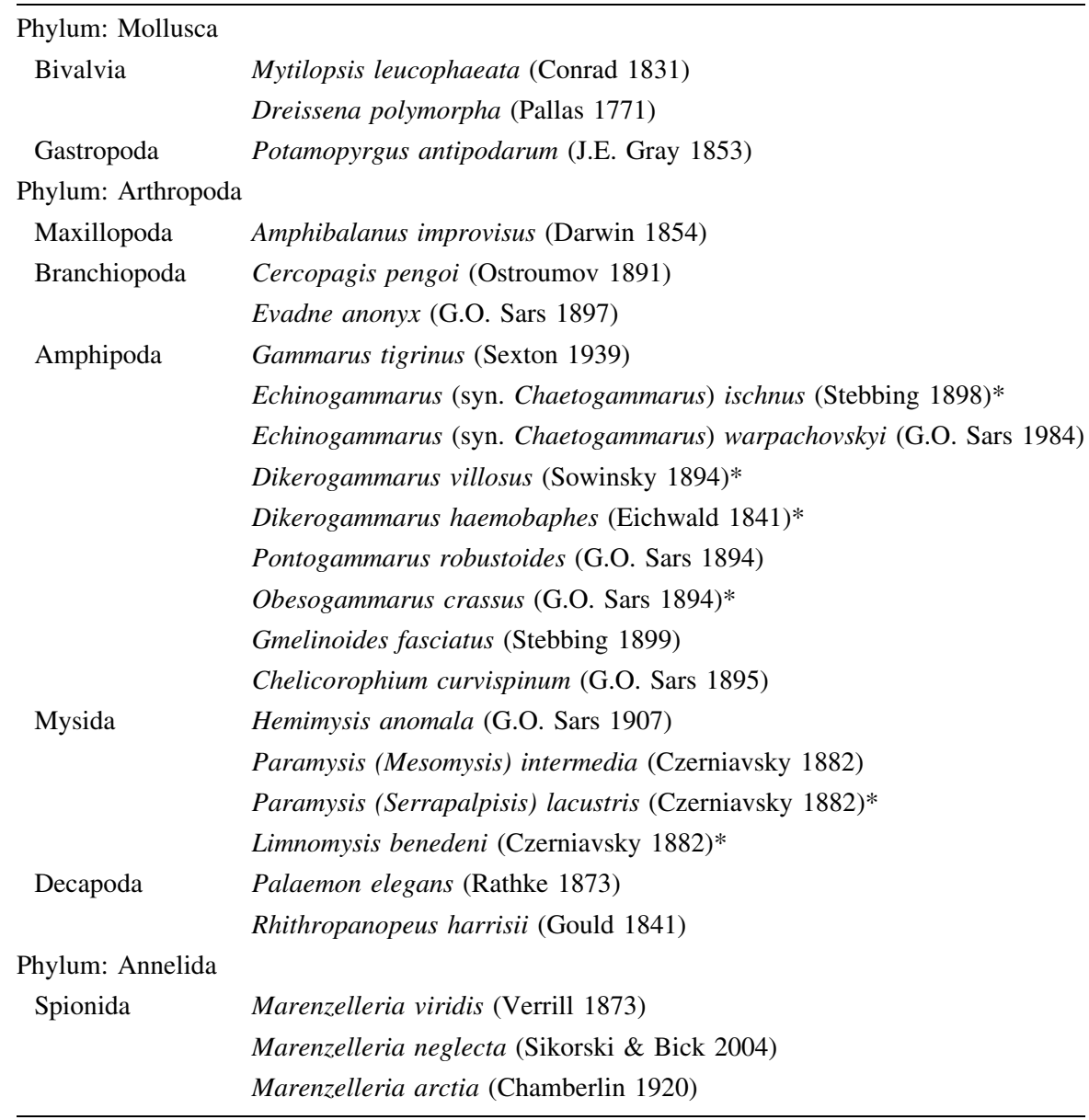

The species not yet present in the northern Baltic Sea, but with dispersal potential are marked with an asterisk the Bothnian Sea may decrease below 6 even in the deepest parts whilst in the deep areas of the Gulf of Finland salinity may still reach 10 . The salinity frequency distribution in the northern Baltic Sea (above $56.9^{\circ} \mathrm{N}$ latitude), with a shift both on the surface and bottom, is shown in Fig. 4.

Results of the literature review

All in all 125 articles and reports were found useful for our review, with a strong focus on papers from the Baltic Sea region and the species' native region. Literature from other areas was used where information otherwise would have been insufficient. Most of the used articles describe the broad environmental conditions where the species have been encountered, whilst physiological optima of the species often remain unknown. Papers deriving their estimates from short-term (24-48 h) mortality studies, for instance in 
(a)

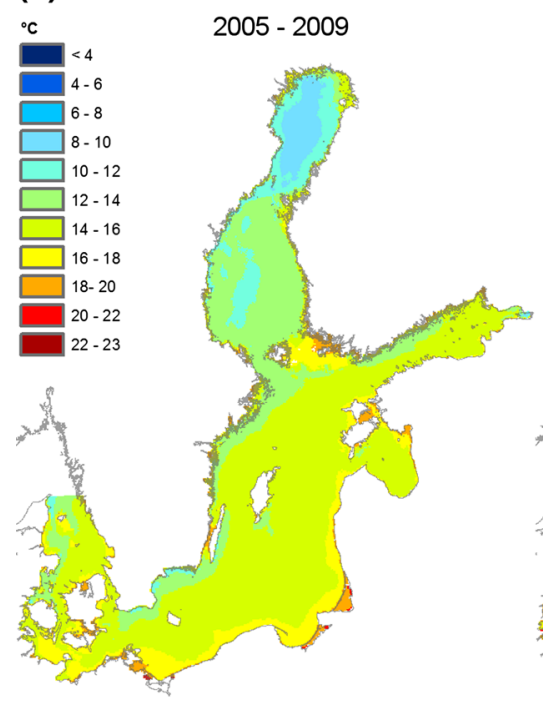

(b)

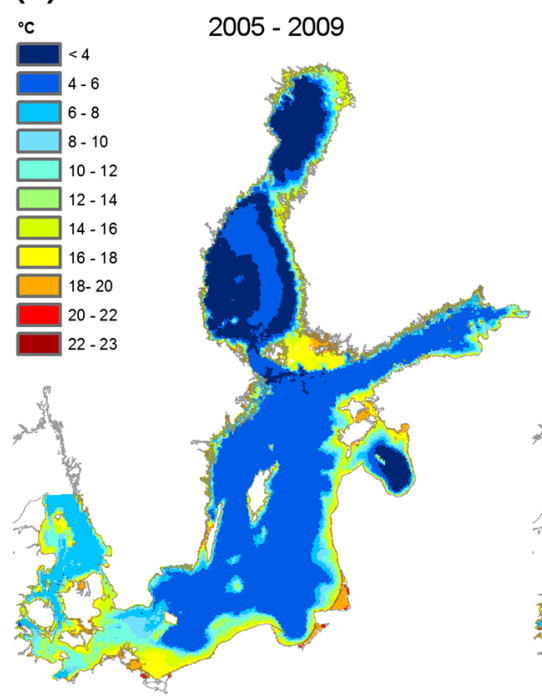

Surface temperature

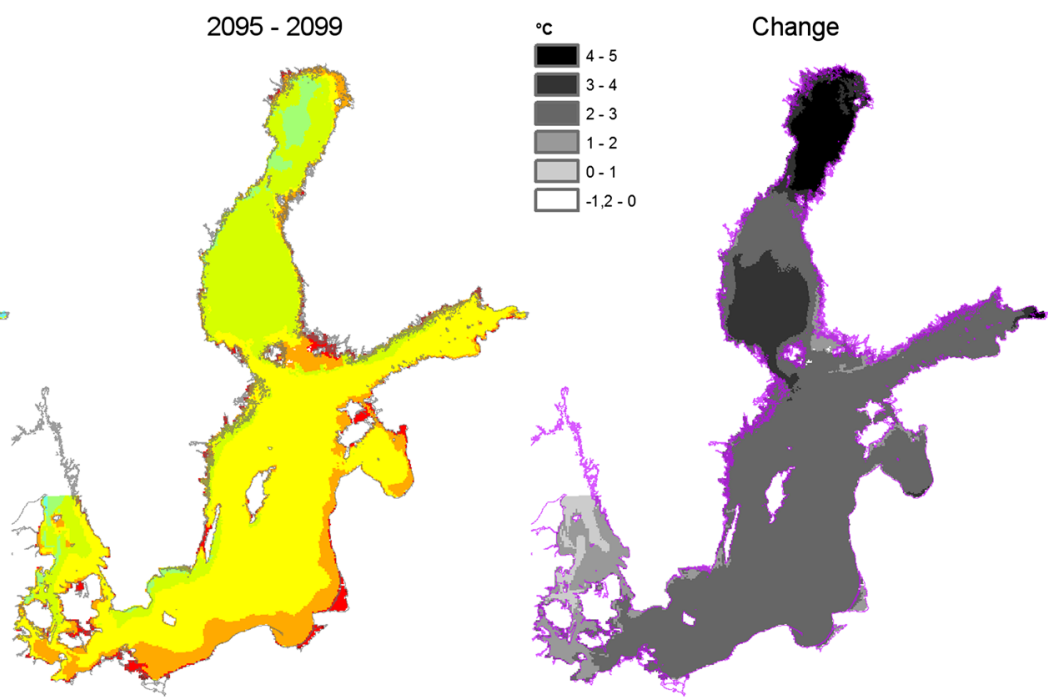

Bottom temperature

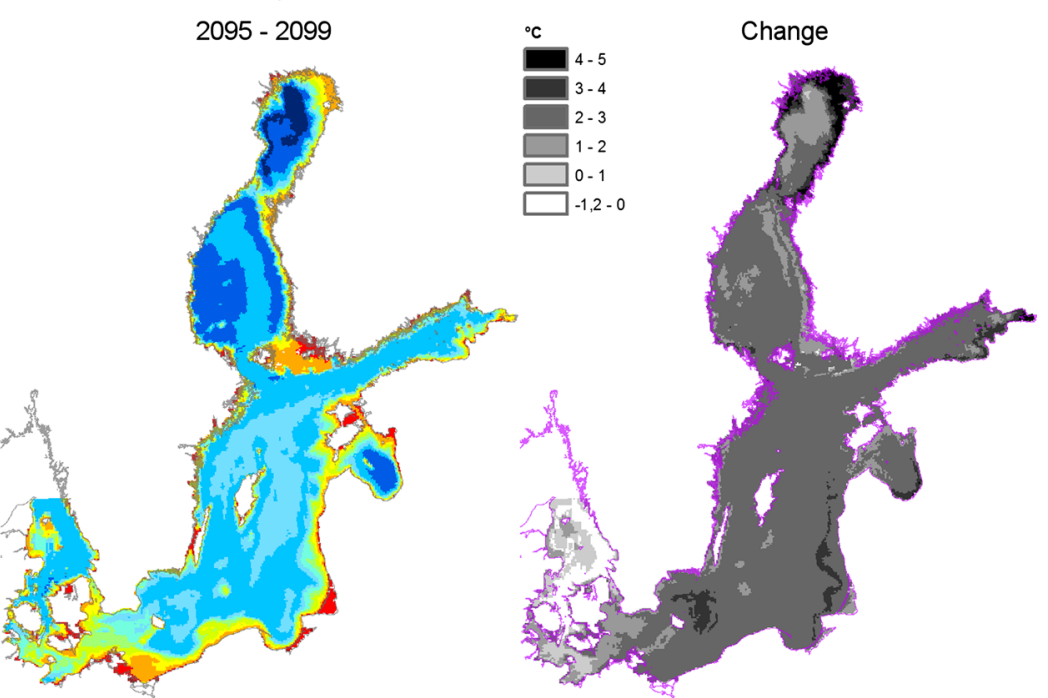

Fig. 2 Average surface (a) and bottom (b) temperatures and the magnitude of change (c) in the Baltic Sea during summer (JuneAugust) in 2005-2009 and in 2095-2099 based on RCO-SCOBI model estimates

ballast water treatment studied, were not included as temperature and salinity do not fluctuate rapidly in the northern Baltic Sea as tidal action is lacking. The full results of literature review and related references can be found in the supporting information Table (S1). In addition to giving information regarding salinity and temperature ranges, both in the field and in laboratory tests for adults, the Table S1 reports these ranges for different reproductive stages, where information is available. Table $\mathrm{S} 1$ also gives the additional information on the general distribution of
NIS in the Baltic Sea and the year of introduction, but does not summarise the global distribution, as this is beyond the scope of this paper and such information can be accessed from global databases. We complimented the literature review zooplankton monitoring data from the Finnish, Swedish and Estonian zooplankton monitoring databases. Based on the literature review and this additional data we next describe the general physiological requirements and tolerances of NIS, and the expected changes due to climate change. 
(a)
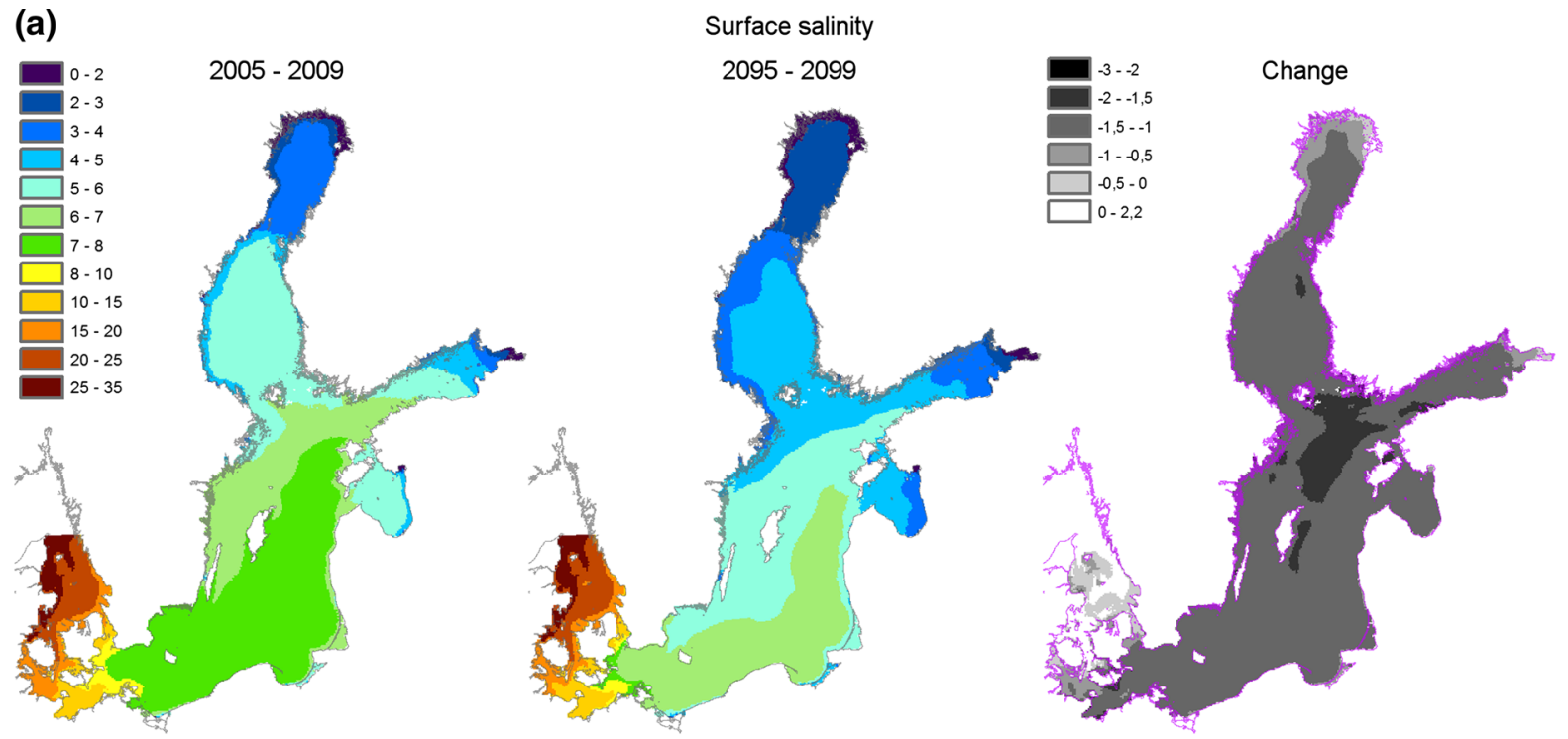

(b)

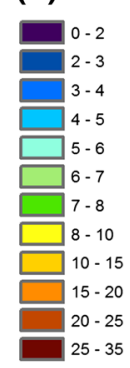

$2005-2009$

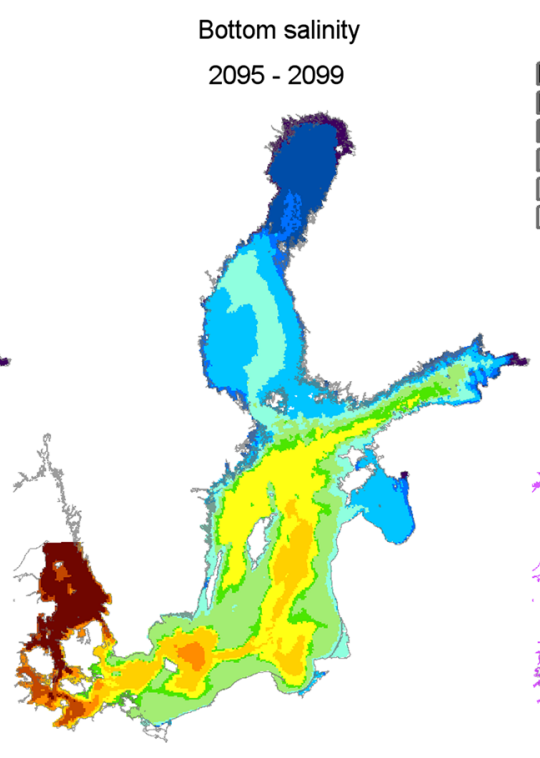

Bottom salinity
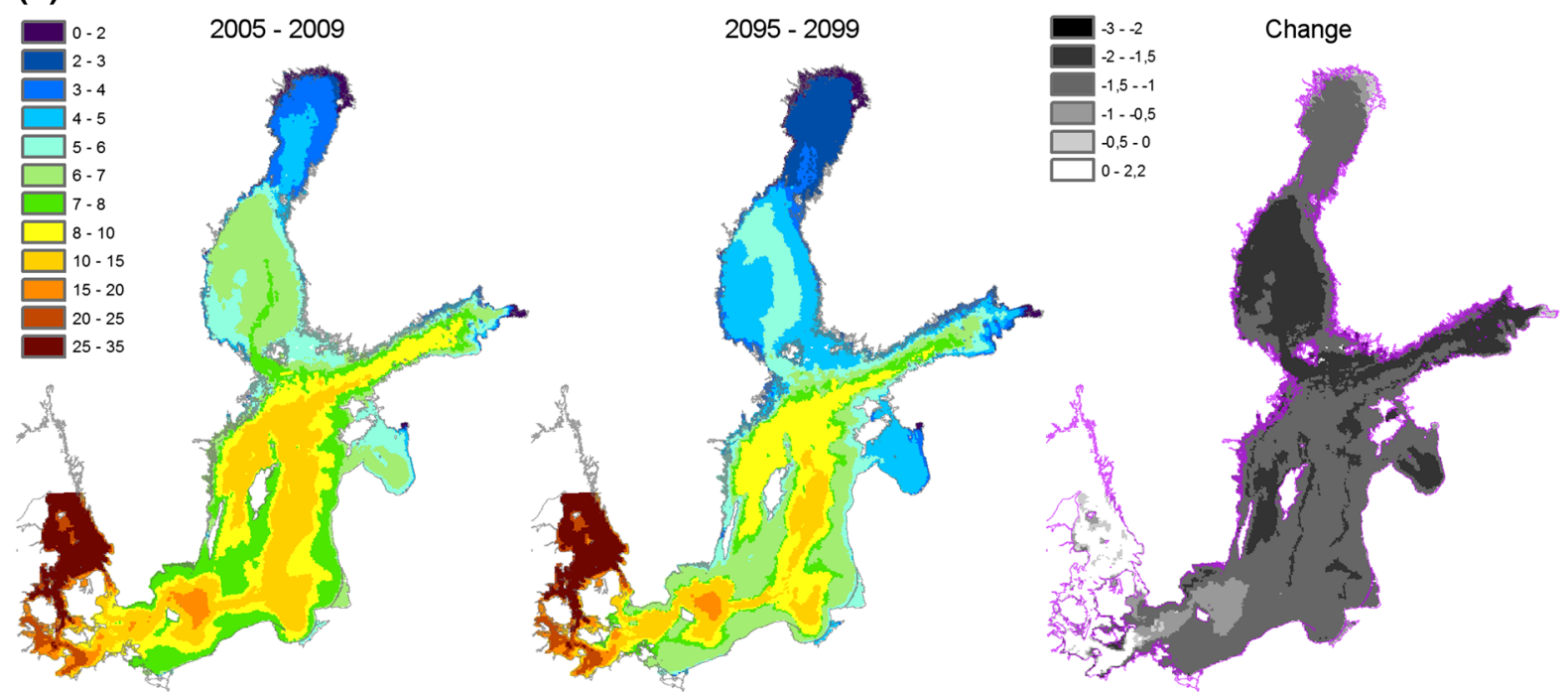

Fig. 3 Average surface (a) and bottom (b) salinities and the magnitude of change (c) in the Baltic Sea during summer (June-August) in 2005-2009 and in 2095-2099 based on RCO-SCOBI model estimates

NIS benefitting from future changes in temperature and salinity

\section{Onychopod cladocerans}

Ponto-Caspian onychopod cladocerans Cercopagis pengoi and Evadne anonyx are euryhaline and in the Baltic Sea they occur in the lower end of their salinity range (Fig. 5; Table S1). In contrast to C. pengoi, E. anonyx has no prior invasion history in freshwater
(Panov et al. 2007) and is encountered in quite a narrow range of salinities in its native origin (Table S1). Both species prefer warm waters but are adapted to wide fluctuations in temperature in their native areas (Rivier 1998). They reach their maximum abundances at temperatures above $15{ }^{\circ} \mathrm{C}$ and typically disappear when temperature drops below $10{ }^{\circ} \mathrm{C}$ (Krylov et al. 1999; Rivier 1998). C. pengoi and E. anonyx reproduce parthenogenically during summer, switch to gametogenetic reproduction when 

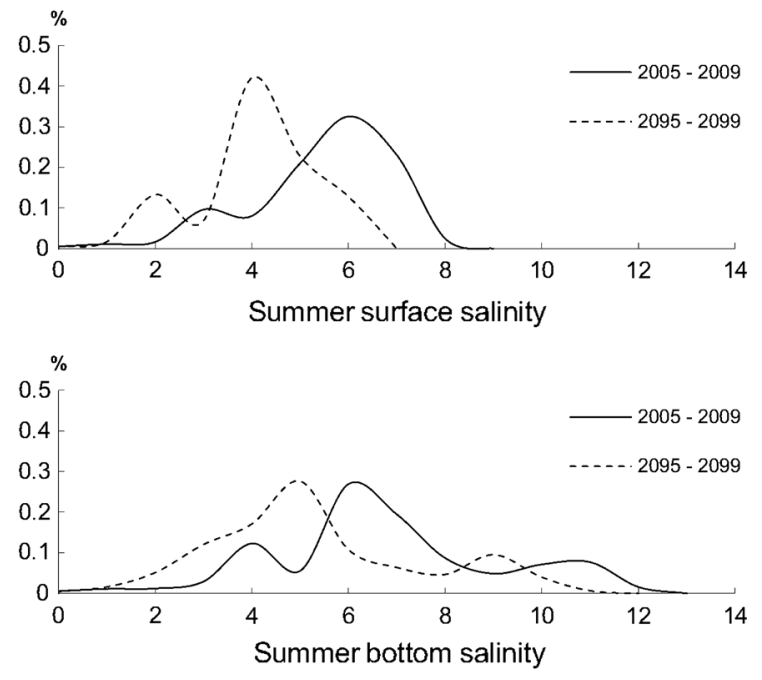

Fig. 4 Frequency distribution of modelled (RCO-SCOBI) present (2005-2009) and future (2095-2099) surface and bottom salinity ranges during summer (June-August) in the northern Baltic Sea (above $56.9^{\circ} \mathrm{N}$ latitude)

temperature falls and survive cold winter as resting eggs (Rivier 1998). C. pengoi hatching from resting eggs may start in temperatures as low as $3-6{ }^{\circ} \mathrm{C}$ (Sopanen 2008). According to national (Estonian, Finnish, Swedish) zooplankton monitoring data, $C$. pengoi abundances are highest (1000-7030 ind. $\mathrm{m}^{-3}$ ) between July and September in $13.1-25.2{ }^{\circ} \mathrm{C}$ and 3.5-5.8 salinity (unpublished). E. anonyx abundances in the same monitoring data are highest (100-1212 ind. $\mathrm{m}^{-3}$ ) between July and August in temperatures $10.8-24.4^{\circ} \mathrm{C}$ and $2.6-8.16$ salinity (unpublished).

Future: $C$. pengoi and E. anonyx are thermophilic species with ability to survive and reproduce in low salinities. Both species are expected to become more abundant and widespread in coastal areas, lagoons and open sea areas, with rising temperature allowing more parthenogenetic generations to succeed.

\section{Bivalve: Dreissena polymorpha}

The Ponto-Caspian dreissenid bivalve Dreissena polymorpha is present in the Baltic Sea in areas with low salinity (Fig. 5; Table S1) as the species reproduction starts to fail when salinity exceeds 3.5 (Fong et al. 1995). D. polymorpha requires temperatures above $10-12{ }^{\circ} \mathrm{C}$ in order for growth and reproduction to occur, and larval occurrence seems to be optimal in 20-25 ${ }^{\circ} \mathrm{C}$ (Fong et al. 1995; Kornobis 1977; Stanczykowska 1977). Veliger larvae of Dreissena spp. stay in the water column for a rather short time, i.e. few to several days (Verween et al. 2010). The low summer temperatures along with shorter invasion history in the northern Baltic Sea in the Gulfs of Riga and Finland (Olenin et al. 1999) explain the lower abundances recorded in North compared to the low-salinity coastal areas in the southern Baltic Sea (Antsulevich et al. 2003; Daunys et al. 2006; Golubkov et al. 2003; Panov et al. 2002).

Future: In the northern Baltic Sea, the current distribution of $D$. polymorpha is limited by high salinity and low temperatures. The unfavourable conditions are reflected in low reproduction, and reduction of size in adults is observed when moving from eastern parts of the Gulf of Finland with low salinity, to west with higher salinity (Antsulevich et al. 2003). D. polymorpha is already locally very abundant in parts of the eastern Gulf of Finland and the Gulf of Riga (Golubkov et al. 2003; Kotta et al. 1998) and is likely to become dominant in many other areas as salinity decreases and temperature increases.

\section{Bivalve: Mytilopsis leucophaeata}

The dreissenid bivalve Mytilopsis leucophaeata is a true brackish water species able to survive from freshwater to almost full marine salinity, although its reproduction is not possible in pure freshwater (Fig. 5; Table S1). Although this species originates from tropical waters in the Gulf of Mexico, with temperatures between 24 and $27{ }^{\circ} \mathrm{C}$, the species has successfully distributed to temperate regions and can survive temperatures down to $6.8^{\circ} \mathrm{C}$ (Marelli and Gray 1983; Verween et al. 2010). Reproduction via veliger larvae occurs when water temperature exceeds $12-13{ }^{\circ} \mathrm{C}$ (Verween et al. 2010). In the Baltic Sea this species has been found in Finland from thermally heated areas near power plants of Loviisa, Olkiluoto and Naantali, but also from the Archipelago Sea with no associated warm water influence (Laine et al. 2006; Ljungberg et al. 2011; Vesakoski, University of Turku, pers. comm.).

Future: M. leucophaeata prefers warm waters and the rising temperatures in the northern Baltic Sea are likely to facilitate the spreading of this species from now quite restricted local habitats. Decreasing salinity should not prevent the spread of this species in most areas, except for areas near major freshwater sources. 
Fig. 5 Salinity occurrence ranges $(<14)$ for NIS in the Baltic Sea (with black) and native origin (with grey) from literature review. Data from other regions is omitted as it gives no further information for low salinity areas. Range for adults is marked with a smooth line (black or grey) and range for reproduction with dots (black or grey). *For clonally reproducing $P$. antipodarum only the optimal reproduction range is given. **For Marenzelleria spp., $R$. harrisii and P. elegans the lower limit for reproduction is known, but the upper limit is unknown and is here marked with a diamond to indicate possible reproduction in higher salinities. For references see Table S1

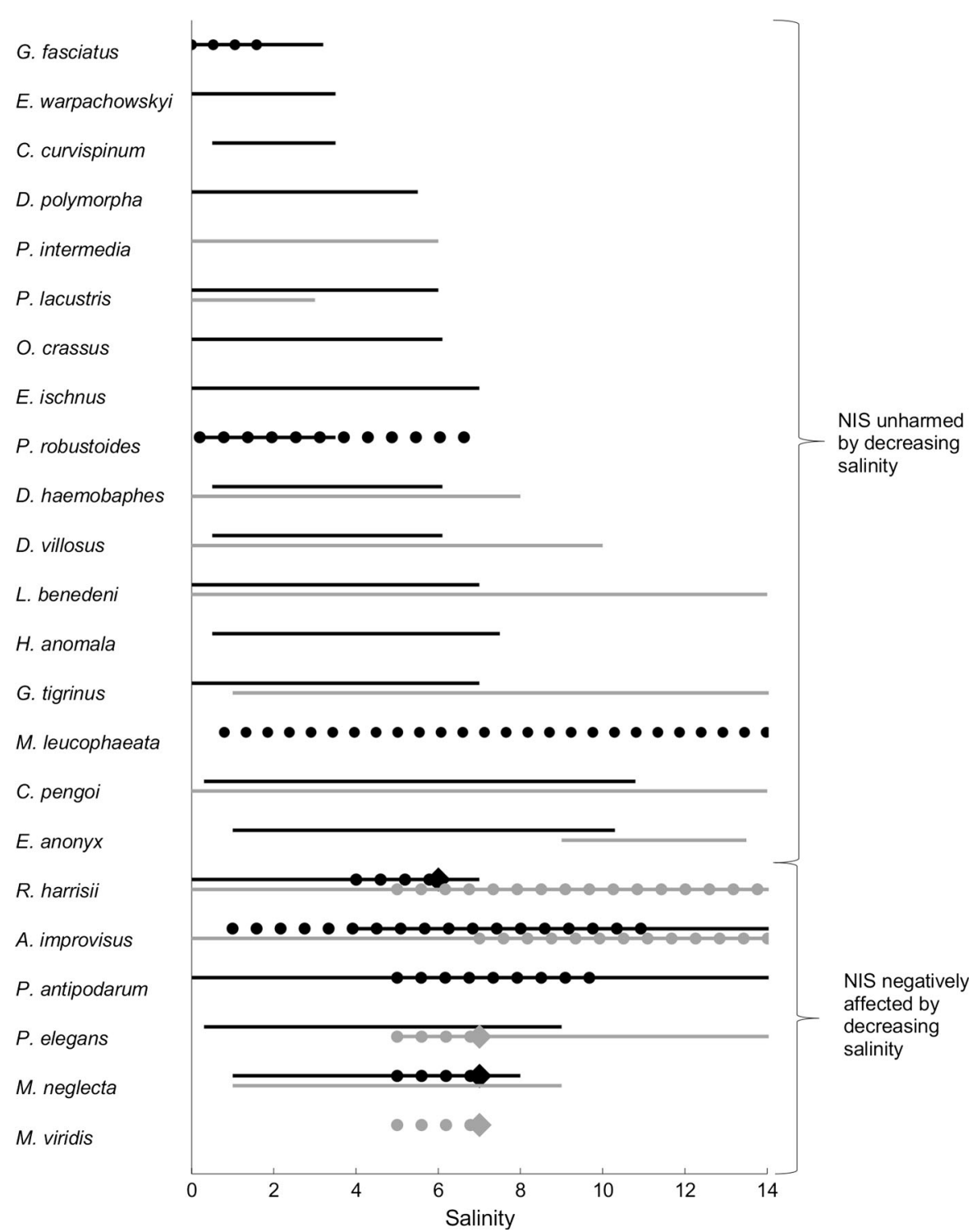

Amphipods

Non-indigenous amphipod crustaceans from PontoCaspian region, North America and East Siberia have been introduced to the Baltic Sea. The North American Gammarus tigrinus has the broadest tolerance to salinity and temperature, the Ponto-Caspian amphipods (Echinogammarus warpachowskyi, Echinogammarus ischnus, Dikerogammarus haemobaphes, Dikerogammarus villosus, Pontogammarus robustoides, Obesogammarus crassus and Chelicorophium curvispinum) and the Siberian Gmelinoides fasciatus preferring low salinities and freshwater (Fig. 5; Table S1). In Europe all of the Ponto-Caspian species, except for E. warpachowskyi, have successfully inhabited many polluted rivers with high ionic content (Grabowski et al. 2009; Grabowski and Konopacka 2007; Kestrup and Ricciardi 2009; Wijnhoven et al. 2003). Adults of G. tigrinus survive temperatures from near zero up to $32.2-34.2^{\circ} \mathrm{C}$ (Sareyka et al. 2011; Wijnhoven et al. 2003) but laboratory exams indicate that the species is not able to reproduce in temperatures below $5{ }^{\circ} \mathrm{C}$ (Pinkster et al. 1977). The PontoCaspian amphipods have a generally wide temperature 
tolerance with their lower occurrence limit ranging from $2-11.3{ }^{\circ} \mathrm{C}$ to upper limit $24-30{ }^{\circ} \mathrm{C}$ (Table S1). The optimal temperature for $G$. fasciatus is below $22{ }^{\circ} \mathrm{C}$ (Berezina and Panov 2004, and references therein), but the species has been found in Neva estuary where temperature may rise up to $27.5{ }^{\circ} \mathrm{C}$ (Berezina and Panov 2003).

Future: All of the non-indigenous amphipods reviewed here survive well in waters with low salinities. These species also have a wide temperature tolerance and there is no reason to assume, that the species would be hindered by future changes in the northern Baltic Sea. Species currently only present in the southern Baltic lagoons (E. ischnus, D. villosus, $D$. haemobaphes and $O$. crassus) have a potential of dispersing to northern Baltic Sea.

\section{Mysids}

Relatively little published information is available regarding the distribution and tolerance of PontoCaspian mysids, to salinity and temperature, in the Baltic Sea. H. anomala is found both in the southern and northern Baltic Sea as well as in the Baltic proper (Janas and Wysocki 2005; Kotta and Kotta 2010; Salemaa and Hietalahti 1993; E. Gorokhova, Stockholm University, pers. obs.). Paramysis (Mesomysis) intermedia has been sighted in the Gulfs of Finland and Riga (Herkül et al. 2009) and Paramysis (Serrapalpisis) lacustris and Limnomysis benedeni are distributed in parts of the Curonian lagoon. Paramysis spp. prefer low salinities, but $H$. anomala and $L$. benedeni can occur also in higher salinities (Fig. 5; Table S1). Generally all of the mysids are found in areas with a wide temperature range (Lesutienè et al. 2007, 2008; Marty 2008).

Future: The non-indigenous mysids have quite a limited distribution in the Baltic Sea, as they prefer low salinities. Hence they can be expected to benefit from decreasing salinity. Paramysis spp. and $L$. benedeni may become more abundant in sheltered sandy and vegetated habitats (Herkül et al. 2009; J. Lesutienè, Klaipeda University, pers. comm.), but are not expected to colonise exposed shores. $H$. anomala inhabits both exposed and sheltered regions (Kotta and Kotta 2010; Salemaa and Hietalahti 1993) and has the potential to further widen its distribution in various shores. The mysids will benefit from rising temperatures, as this allows more successive generations to arise.

NIS negatively affected by future changes in temperature and salinity

\section{Cirriped: Amphibalanus improvisus}

Amphibalanus improvisus is adapted to less saline water than other cirripeds (Lang and AckenhusenJohns 1981) and the Baltic populations exhibit better physiological and behavioural adaptation to low salinities than those from the Atlantic (Furman 1989). However the distribution in the northern Baltic Sea is limited by low salinity (Fig. 5; Table S1) in the Bothnian Bay (Vaasa) and in the Gulf of Finland (Luther 1950; Segerstråle 1957). A. improvisus is able to tolerate wide range of temperature $\left(2-30{ }^{\circ} \mathrm{C}\right)$, briefly even down to freezing point (Furman 1989; Lang and Ackenhusen-Johns 1981; Moore and Frue 1959; Southward 1957). In the national (Estonian, Finnish and Swedish) zooplankton monitoring data, A. improvisus larvae are found all year in the water column, and the highest abundances $\left(10,000-195,918\right.$ ind. $\left.\mathrm{m}^{-3}\right)$ occur in 11.0-23.0 ${ }^{\circ} \mathrm{C}$ and 2.9-6.1 salinity between June and August (unpublished). The exact salinity limit for successful reproduction in the Baltic Sea is not known, but as adults are sessile we assume it to be the similar to adult distribution limits. Furman (1989) has suggested that not all of the larvae in the northern Baltic Sea finish development during winter. Nor are they able to settle in areas with low salinity.

Future: A. improvisus cannot live in the northern Baltic Sea in areas of low salinity, although larvae can be frequently found in such areas. On the Finnish coast of the Gulf of Bothnia it is expected that the northern distribution limit of A. improvisus by end of the twenty-first century will shift from the Quark to the middle parts of the Bothnian Sea along the Finnish coast. On the Swedish coast of the Gulf of Bothnia the salinity is, due to anticyclonic circulation, generally lower than on the Finnish side, and the species may largely disappear. In the Gulf of Finland the distribution limit will shift westward. In both areas the species may persist in areas where the surface salinity remains mostly above 3-4. 
Polychaetes: Marenzelleria spp.

Three species of Marenzelleria genus have been recorded in the Baltic Sea (Bastrop and Blank 2006; Blank and Bastrop 2009; Blank et al. 2008). Marenzelleria neglecta and Marenzelleria viridis are native to the Atlantic coast of North America and M. neglecta additionally to the Pacific coast of North America and the Arctic region. Marenzelleria arctia is native to the Arctic region. According to molecular identification techniques both $M$. neglecta and M. arctia are present in the northern Baltic Sea (Bastrop and Blank 2006; Blank et al. 2008) and based on this distribution both species are able to adapt to fairly low salinities as adults, although the physiological tolerance limits of adults are unknown (Table S1). M. viridis may be limited to more saline areas and has only been found in the Gulf of Riga and south-western Bothnian Sea in the northern Baltic Sea (Bastrop and Blank 2006; Blank et al. 2008). In tidal areas M. neglecta is known to prefer lower salinities than M. viridis (Blank et al. 2004). $M$. arctia in its native region occurs in river estuaries where the salinity varies from freshwater to almost full salinity (Jørgensen et al. 1999), but the reproduction and recruitment most likely take place during winter when intrusions of saline water occur (A. Maximov, Zoological Institute of Russian Academy of Sciences, pers. comm.). The reproduction of $M$. neglecta and $M$. viridis is not possible in very low salinities (Fig. 5; Table S1). All Marenzelleria species are tolerant to temperatures near $0{ }^{\circ} \mathrm{C}$ (Blank and Bastrop 2009). M. neglecta and M. viridis have high upper temperature tolerances as thermal stress and mortality increase only after $30-34$ and $25-30{ }^{\circ} \mathrm{C}$ respectively (Blank et al. 2006). M. arctia in the eastern Gulf of Finland prefers deeper bottoms than $M$. neglecta exhibiting possible preference to lower temperatures (Kauppi et al. 2015; Maximov 2011).

Future: Although some larval stages of M. neglecta and $M$. viridis are able to survive low salinities, the entire reproduction cycle completement requires salinity of 5, and hence these species are likely to become less abundant in the northern Baltic Sea. For $M$. arctia the ability to reproduce in stable low salinity conditions is unknown, but the species currently seems to prefer deeper water in the Baltic Sea, perhaps indicating better survival in areas with cool and saline waters. It is likely that also this species will become less abundant in the future.

\section{Gastropod: Potamopyrgus antipodarum}

Potamopyrgus antipodarum originates from freshwater and estuaries of New Zealand and currently has global distribution. In the northern Baltic Sea the species is restricted to brackish water, with an exception of being found in lakes in Åland Islands (Jensen 2010; Nicol 1936). P. antipodarum in Europe and North America are entirely clonal, parthenogenetic and have no larval reproduction (Dybdahl and Kane 2005; Luther 1950; Wallace 1992). P. antipodarum clones in Denmark (and supposedly occupying the entire Baltic Sea) have higher reproductive output in intermediate salinities (Fig. 5; Table S1) than in freshwater or higher salinities and adults show similar salinity optima for growth and feeding rates (Jacobsen and Forbes 1997). This species can be found in areas with $0-32{ }^{\circ} \mathrm{C}$ temperature (Hylleberg and Siegismund 1987), but the optimal temperature for reproduction lies near $18{ }^{\circ} \mathrm{C}$ (Dybdahl and Kane 2005).

Future: $P$. antipodarum can currently be found almost in the entire Baltic Sea even though its reproduction might be optimal in salinities above 5 . The species may decrease in abundance in areas with almost freshwater salinities. However total disappearance of the species from northern Bothnian Bay and eastern Gulf of Finland is not expected.

\section{Shrimp: Palaemon elegans}

Palaemon elegans is an eurythermal species distributed in the Atlantic, including Kattegat region of the Baltic Sea, and further in the Mediterranean and Black Sea (Berglund 1980; Janas et al. 2004, and references therein). Reuschel et al. (2010) have shown that the specimen in the southern Baltic Sea share the same haplotype with the populations from Black Sea and Mediterranean Sea and that the invasion of the Baltic Sea during the early 2000's is probably from these populations. Janas and Spicer (2010) have also shown that $P$. elegans from the Baltic Sea hyperregulate more efficiently in low salinities and low temperatures than specimen from the North Sea. $P$. elegans in the Baltic Sea can be found in salinities even close to freshwater (Fig. 5; Table S1). In Kattegat - a sea area connecting North Sea to the Baltic Sea-P. elegans larvae cannot survive in salinities below 5, with the optimum above 10 (Berglund 1985). It is unknown whether populations 
in the Baltic Sea are able to reproduce in lower salinities, or whether juveniles or adults migrate to low salinity areas.

Future: Although the reproduction limits of $P$. elegans in the northern Baltic Sea are unknown it is likely that $P$. elegans, originally a marine species, will suffer from the decreasing salinities and that the distribution limits in the Gulf of Finland and Bothnian Sea will shift westward and southward, respectively. The species will likely become less abundant in the northern Baltic Sea.

\section{Crab: Rhithropanopeus harrisii}

Rhithropanopeus harrisii is an unusually eurythermal and euryhaline decapod species. In its native region in the Gulf of Mexico temperature rises up to $30{ }^{\circ} \mathrm{C}$ (Costlow et al. 1966) but in the Baltic Sea the species survives freezing temperatures (Turoboyski 1973). The species is able to live as adults in freshwater and in reservoirs in Texas reproduction occurs in 0.5-3 salinities (Boyle and Pfau 2010, and references therein). However, according to Costlow et al. (1966) larval hatching is not possible in salinities below 5 and in the Baltic Sea reproduction begins in $14{ }^{\circ} \mathrm{C}$ (Turoboyski 1973) and is limited by salinities below 4 (Fig. 5; Table S1).

Future: In the future conditions $R$. harrisii can be expected to have reduced reproduction success in the northern Baltic Sea due to decreasing salinity.

\section{Discussion}

Consequences of climate change on NIS in the northern Baltic Sea

The northern Baltic Sea is shaped by multiple biological invasions and climate change will further alter the ecosystem by end of the twenty-first century. Based on salinity scenarios, the non-indigenous onychopod cladocerans, amphipods, mysids and dreissenid mussel Dreissena polymorpha will more or less benefit from climate change. Mytilopsis leucophaeata dreissenid does not directly benefit from decrease in salinity, but warming would increase the reproduction success of both dreissenids. Rising temperature and prolonged growth season may also enable more intraannual parthenogenetic generations in zooplankton
(Simm and Ojaveer 2006) and broods in amphipods and mysids. The NIS negatively affected from decreasing salinities include marine species (Amphibalanus improvisus, Marenzelleria spp., Palaemon elegans and Rhithropanopeus harrisii) and a brackish water snail Potamopyrgus antipodarum. The earlier suggested benefit of rising temperature for A. improvisus and Marenzelleria spp. (Ojaveer et al. 2011) could be limited by decrease in salinity.

Temperature rise during the twenty-first century is unlikely to cause metabolic stress on NIS as they inhabit wide range of temperatures and the mean surface temperature in the northern Baltic Sea will remain mostly below $23{ }^{\circ} \mathrm{C}$. Decreasing salinity plays a more crucial role, as adaptation physiologically to brackish water is more demanding than adaptation to rising temperatures (Somero 2012). Species with marine background are often unable to cross the salinity 5 isoline (Remane 1934). Even brackish water species which have managed to invade freshwater often face serious physiological challenges in low ion environments (Dietz et al. 1996; Taylor and Harris 1986). Although P. elegans and A. improvisus already exhibit high physiological and behavioural adaptations to low salinities in the Baltic Sea (Furman 1989; Janas and Spicer 2010), it is likely that, without further significant genetic or physiological adaptation, these species along with Marenzelleria spp., R. harrisii and $P$. antipodarum, will decrease in abundance in the northern Baltic Sea during the twenty-first century.

Uncertainties in the climate change projections

The climate change projections include an element of uncertainty which we have not taken into account in this study. This uncertainty arises from biases of the global and regional climate models, unknown future anthropogenic greenhouse gas and aerosol emissions, and natural variability within the climate system that hides anthropogenically induced trends in climate. To include some of this uncertainty in the future estimates, an ensemble of scenario simulations was used. However, the ensemble is too small to investigate the inherent uncertainties thoroughly. For instance, only one model for each of the three sub-domains-the regional atmosphere, ocean and land surface hydrology-is used in the state-of-art Baltic models, making the estimation of uncertainties caused by the biases of the regional climate models impossible (Meier et al. 
2012). The author team of the second Baltic Sea Assessment of Climate Change (BACC II 2014) has concluded that in the future Baltic Sea annual mean water temperature will increase and sea ice extent will decrease. And although all existing scenario simulations suggest decrease in salinity, these changes are considered uncertain as climate models have severe biases with regard to the water balance. The only study investigating salinity projections with a relatively large ensemble found that the salinity changes are either negative or statistically insignificant in terms of natural variability (Meier et al. 2006). Hence, we cannot be absolutely certain whether or not the Baltic Sea salinity will increase or decrease (BACC II 2014). The impact of salinity changes on NIS discussed in this study should be carefully assessed in future studies which would benefit from regional climate models with improved water balance, hydrodynamic models with finer spatial resolution, and an increase in the number of climate change simulations.

Our study only considered the impacts of climate change on salinity and temperature, but acidification and changes in calcium saturation (Chierici and Fransson 2009; Tyrrell et al. 2008; Whittier et al. 1995), eutrophication and hypoxia (Meier et al. 2012; Neumann et al. 2012; Omstedt et al. 2012) along with changing species-interactions may also shape the future NIS communities in the northern Baltic Sea. Such changes are not measurable without further studies, but they do not affect the general responses of NIS to salinity and temperature changes.

\section{Potential impacts of NIS on the northern Baltic Sea ecosystem}

Despite uncertainties in climate change projections, the potential outcome of projected salinity and temperature changes should be acknowledged, as changes posed to NIS may impact the northern Baltic Sea ecosystem and its usage in various ways. Literature on the impacts of NIS in the Baltic Sea has been reviewed e.g. by Zaiko et al. (2011) and although in many aspects the information on impacts of NIS in the Baltic Sea is still limited (Ojaveer and Kotta 2014), we shortly discuss few important recognized impacts.

Despite the long invasion history, the impacts of $P$. antipodarum and A. improvisus have remained low and moderate in the northern Baltic Sea, respectively (Zaiko et al. 2011) and the withdrawal of these species is not expected to substantially impact the future ecosystem of the Baltic Sea. A. improvisus fouling impact on leisure boating may become reduced. Marenzelleria species as fairly recent invaders in the northern Baltic Sea have become dominant in numerous areas and various nutrient-sediment interactions, such as hypoxia mitigation and nutrient retention (Maximov et al. 2014; Norkko et al. 2012) or controversially nutrient release (Viitasalo-Frösén et al. 2009), have been linked with their bioturbation activities. The decrease in Marenzelleria spp. abundance may effect nutrient cycles in an unexpected way that future studies should try to further understand (Maximov et al. 2015).

Almost all of the NIS expected to benefit from climate change have shown some negative impacts in the Baltic Sea (Zaiko et al. 2011), though not all of their impacts are merely harmful. C. pengoi has decreased the numbers of some important native zooplankton species in the Baltic Sea (Gorokhova et al. 2005; Lehtiniemi and Gorokhova 2008), but it also serves as a food source for planktivore fish (Kotta et al. 2006; Ojaveer et al. 2000). D. polymorpha mussel beds recycle nutrients and have been proposed to facilitate filamentous algal growth in the Gulf of Finland (Orlova et al. 2006). D. polymorpha may also become a severe biofouler with $M$. leucophaeata (Laine et al. 2006), but at the same time these species may fill an empty niche that the withdrawal of marine key species blue mussel (Mytilus trossulus x M. edulis) due to climate change may leave behind (Leth et al. 2013). Most of the non-indigenous amphipods are able to efficiently out-compete or predate on native amphipods and mysids (Grabowski et al. 2007; Orlova et al. 2006; Surowiec and Dobrzycka-Krahel 2008). On the other hand they serve as food for several fish in the Baltic Sea (Daunys and Zettler 2006) and some species may decrease the biomass of filamentous Cladophora algae (Golubkov et al. 2003; Orlova et al. 2006).

Support for global theories on climate change promoting success of the non-indigenous species

According to Qian and Ricklefs (2006) anecdotal evidence suggests that climate change will not substantially decrease the impacts of current invasive species. This seems to be true in the northern Baltic Sea where the number of non-indigenous invertebrate 
species expected to benefit from temperature and salinity changes is higher than the number of negatively affected NIS. Although the impacts of some extant invasive species may reduce, the overall impacts of NIS may increase as majority of these species can be expected to expand their distribution range and increase in abundance. Even without further introductions of NIS to the Baltic Sea, the overall response of NIS to climate change is more than a zerosum (Hellmann et al. 2008) in the northern basins. Our study confirms that in brackish water ecosystem, changes in hydrology and thereby on salinity are able to widely alter the NIS communities. Moreover, rising temperature can further increase the abundance of NIS. The suggested changes are ecologically significant in the northern Baltic Sea where natural biodiversity is relatively low.

Acknowledgments This study was funded by MARISPLAN project (Academy of Finland), the Swedish Environmental Protection Agencýs National Marine Monitoring Program, Stockholm University's strategic marine environmental research program Baltic Ecosystem Adaptive Management and the Estonian Research Council (Institutional research funding IUT02-20). Anders Höglund (Swedish Meteorological and Hydrological Institute) and Byoung Woon An (Finnish Meteorological Institute) are acknowledged for their help in the SMHI RCO-SCOBI model data delivery, Jūrate Lesutienè (Klaipeda University) for her advice regarding the PontoCaspian mysids, Anni Arponen (University of Helsinki) for the constructive criticism on the article manuscript and Swedish Meteorological and Hydrological Institute is acknowledged for the Swedish environmental data.

Open Access This article is distributed under the terms of the Creative Commons Attribution 4.0 International License (http:// creativecommons.org/licenses/by/4.0/), which permits unrestricted use, distribution, and reproduction in any medium, provided you give appropriate credit to the original author(s) and the source, provide a link to the Creative Commons license, and indicate if changes were made.

\section{References}

Antsulevich AE, Välipakka P, Vaittinen J (2003) How are the zebra mussels doing in the Gulf of Finland? Proc Estonian Acad Sci Biol Ecol 52:268-283

Bacc II (2014) Second assessment of climate change for the Baltic Sea Basin. Springer, Berlin

Bastrop R, Blank M (2006) Multiple invasions-a polychaete genus enters the Baltic Sea. Biol Invasions 8:1195-1200

Berezina NA, Panov VE (2003) Establishment of new gammarid species in the eastern Gulf of Finland (Baltic Sea) and their effects on littoral communities. Proc Estonian Acad Sci Biol Ecol 52:284-304

Berezina NA, Panov VE (2004) Distribution, population structure and salinity tolerance of the invasive amphipod Gmelinoides fasciatus (Stebbing) in the Neva Estuary (Gulf of Finland, Baltic Sea). Hydrobiologia 514:199-206

Berglund A (1980) Niche differentiation between two littoral prawns in Gullmar Fjord, Sweden: Palaemon adspersus and $P$. squilla. Holarct Ecol 3:111-115

Berglund A (1985) Different reproductive success at low salinity determines the estuarine distribution of two Palaemon prawn species. Holarct Ecol 8:49-52

Blank M, Bastrop R (2009) Phylogeny of the mud worm genus Marenzelleria (Polychaeta, Spionidae) inferred from mitochondrial DNA sequences. Zool Scr 38:313-321

Blank M, Bastrop R, Röhner M et al (2004) Effect of salinity on spatial distribution and cell volume regulation in two sibling species of Marenzelleria (Polychaeta: Spionidae). Mar Ecol Prog Ser 271:193-205

Blank M, Bastrop R, Jürss K (2006) Stress protein response in two sibling species of Marenzelleria (Polychaeta: Spionidae): Is there an influence of acclimation salinity? Comp Biochem Physiol B: Biochem Mol Biol 144:451-462

Blank M, Laine A, Jürss K et al (2008) Molecular identification key based on PCR/RFLP for three polychaete sibling species of the genus Marenzelleria, and the species' current distribution in the Baltic Sea. Helgol Mar Res 62:129-141

Boyle TJ, Pfau KD (2010) Occurence, reproduction, and population genetics of the estuarine mud crab, Rhithropanopeus harrisii (Gould) (Decapoda, panopidae) in Texas freshwater reservoirs. Crustaceana 83:493-505

Brady CE, Somero GN (2006a) Ecological gradients and relative abundance of native (Mytilus trossulus) and invasive (Mytilus galloprovincialis) blue mussels in the California hybrid zone. Mar Biol 148:1249-1264

Brady CE, Somero GN (2006b) Following the heart: temperature and salinity effects on heart rate in native and invasive species of blue mussels (genus Mytilus). J Exp Biol 209:2554-2566

Chierici M, Fransson A (2009) Calcium carbonate saturation in the surface water of the Arctic Ocean: undersaturation in freshwater influences shelves. Biogeosciences 6(2421):2432

Costlow JD, Bookhout CG, Monroe RT (1966) Studies on the larval development of the crab, Rhithropanopeus harrisii (Gould). I. The effect of salinity and temperature on larval development. Physiol Zool 39:81-100

Daunys D, Zettler ML (2006) Invasion of the North American amphipod (Gammarus tigrinus Sexton, 1939) into the Curonian lagoon, south-eastern Baltic Sea. Acta Zool Litu 16:20-26

Daunys D, Zemlys P, Olenin S et al (2006) Impact of the zebra mussel Dreissena polymorpha invasion on the budget of suspended material in a shallow lagoon system. Helgol Mar Res 60:113-120

Dietz TH, Wilcox SJ, Byrne RA et al (1996) Osmotic and ionic regulation of North American zebra mussels (Dreissena polymorpha). Am Zool 36:364-372

Dukes JS, Mooney HA (1999) Does global change increase the success of biological invaders? Trends Ecol Evol 14:135-139 
Dybdahl MF, Kane SL (2005) Adaptation vs. phenotypic plasticity in the success of a clonal invader. Ecology 86:1592-1601

Fong PP, Kyozuka K, Duncan J et al (1995) The effect of salinity and temperature on spawning and fertilization in the Zebra mussel Dreissena polymorpha (Pallas) from North America. Biol Bull 189:320-329

Furman ER (1989) The taxonomic relationship of Balanus improvisus (Darwin) populations in the Baltic and the Atlantic. School of Ocean Sciences, University College of North Wales, Menai Bridge, p 136

Gallardo B, Aldridge DC (2013) Evaluating the combined threat of climate change and biological invasions on endangered species. Biol Conserv 160:225-233

Golubkov SM, Bäck S, Nikulina VN et al (2003) Effects of eutrophication and invasion of Dreissena polymorpha in the coastal zone of the eastern Gulf of Finland. Proc Estonian Acad Sci Biol Ecol 52:218-235

Gorokhova E, Hansson S, Hoglander H et al (2005) Stable isotopes show food web changes after invasion by the predatory cladoceran Cercopagis pengoi in a Baltic Sea bay. Oecologia 143:251-259

Grabowski M, Konopacka A (2007) How to be and invasive gammaric (Amphipoda: Gammaroidea) - comparison of life history traits. Hydrobiologia 590:75-84

Grabowski M, Jażdżewski K, Konopacka A (2007) Alien crustaceans in Polish waters-Amphipoda. Aquat Invasions 2:25-38

Grabowski M, Bacela K, Konopacka A et al (2009) Salinityrelated distribution of alien amphipods in rivers provides refugia for native species. Biol Invasions 11:2107-2117

Hampe A, Petit RJ (2005) Conserving biodiversity under climate change: the rear edge matters. Ecol Lett 8:461-467

Hellmann JJ, Byers JE, Bierwagen BG et al (2008) Five potential consequences of climate change for invasive species. Conserv Biol 22:534-543

Herkül K, Kotta J, Püss T et al (2009) Crustacean invasions in the Estonian coastal sea. Estonian J Ecol 58:313-323

Hylleberg J, Siegismund HR (1987) Nice overlap in mud snails (Hydrobiidae): freezing tolerance. Mar Biol 94:403-407

IPCC (2013) Climate change 2013: the physical science basis. Contribution of Working Group I to the Fifth Assessment Report of the Intergovernmental Panel on Climate Change. In: Stocker TF, Qin D, Plattner G-K, Tignor M, Allen SK, Boschung J, Nauels A, Xia Y, Bex V and Midgley PM (eds) Cambridge University Press, Cambridge, New York

Jacobsen R, Forbes VE (1997) Clonal variation in life-history traits and feeding rates in the gastropod, Potamopyrgus antipodarum: performance across a salinity gradient. Funct Ecol 11:260-267

Janas U, Spicer JI (2010) Seasonal and temperature effects on osmoregulation by the invasive prawn Palaemon elegans Rathke, 1837 in the Baltic Sea. Mar Biol Res 6:333-337

Janas U, Wysocki P (2005) Hemimysis anomala G.O. Sars, 1907 (Crustacea, Mysidacea)_first record in the Gulf of Gdańsk. Oceanologia 47:405-408

Janas U, Zarzycki T, Kozik P (2004) Palaemon elegans-a new component of the Gulf of Gdańsk macrofauna. Oceanologia 46:143-146

Jensen KR (2010) NOBANIS_-Invasive alien species fact sheet-Potamopyrgus antipodarum. In: Identification key to marine invasive species in Nordic waters-NOBANIS. www.nobanis.org. Accessed: 21 Mar 2014

Jones MC, Cheung WWL (2014) Multi-model ensemble projections of climate change effects on global marine biodiversity. ICES J Mar Sci 72:741-752

Jørgensen LL, Pearson TH, Anisimova NA et al (1999) Environmental influences on benthic fauna associations of the Kara Sea (Arctic Russia). Polar Biol 22:395-416

Kauppi L, Norkko A, Norkko J (2015) Large-scale species invasion into a low-diversity system: spatial and temporal distribution of the invasive polychaetes Marenzelleria spp. in the Baltic Sea. Biol Invasions 17:2055-2074

Kernan M (2015) Climate change and the impact of invasive species on aquatic ecosystems. Aquat Ecosyst Health Manage 18:321-333

Kestrup ÅM, Ricciardi A (2009) Environmental heterogeneity limits the local dominance of an invasive freshwater crustacean. Biol Invasions 11:2095-2105

Kornobis S (1977) Ecology of Dreissena polymorpha (Pal.) (Dreissenidae, Bivalvia) in lakes receiving heater water discharges). Pol Arch Hydrobiol 24:461-530

Kotta J, Kotta I (2010) The first finding of the Ponto-Caspian mysid shrimp Hemimysis anomala G. O. Sars (Mysidae) in the Estonian coastal sea. Estonian J Ecol 59:230-236

Kotta J, Orav H, Kotta I (1998) Distribution and filtration activity of the zebra mussel, Dreissena polymorpha, in the Gulf of Riga and the Gulf of Finland. Proc Estonian Acad Sci Biol Ecol 47:32-41

Kotta J, Kotta I, Simm M et al (2006) Ecological consequences of biological invasions: three invertebrate case studies in the north-eastern Baltic Sea. Helgol Mar Res 60:106-112

Krylov PI, Bychenkov DE, Panov VE et al (1999) Distribution and seasonal dynamics of the Ponto-Caspian invader Cercopagis pengoi (Crustacea, Cladocera) in the Neva Estuary (Gulf of Finland). Hydrobiologia 393:227-232

Laine AO, Mattila J, Lehikoinen A (2006) First record of the brackish water dreissenid bivalve Mytilopsis leucophaeata in the northern Baltic Sea. Aquat Invasions 1:38-41

Lang WH, Ackenhusen-Johns A (1981) Seasonal species composition of barnacle larvae (Cirripedia: Thoracica) in Rhode Island waters, 1977-1978. J Plankton Res 3:567-575

Lehtiniemi M, Gorokhova E (2008) Predation of the introduced cladoceran Cercopagis pengoi on the native copepod Eurytemora affinis in the northern Baltic Sea. Mar Ecol Prog Ser 362:193-200

Leppäkoski E, Olenin S (2000) Non-native species and rates of spread: lessons from the brackish Baltic Sea. Biol Invasions 2:151-163

Leppäkoski E, Olenin S, Gollasch S (2002) The Baltic Sea - a field laboratory for invasion biology. In: Leppäkoski E, Olenin S, Gollasch S (eds) Invasive aquatic species of Europe-distribution, impacts and management. Kluwer, Dordrecht, pp 253-259

Leppäranta M, Myrberg K (2009) Physical oceanography of the Baltic Sea. Springer, Berlin

Lesutiene J, Gorokhova E, Gasiunaite ZR et al (2007) Isotopic evidence for zooplankton as an important food source for the mysid Paramysis lacustris in the Curonian Lagoon, the South-Eastern Baltic Sea. Estuar Coast Shelf Sci 73:73-80 
Lesutienè J, Gorokhova E, Gasiunaite ZR et al (2008) Role of mysid seasonal migrations in the organic matter transfer in the Curonian Lagoon, south-eastern Baltic Sea. Estuar Coast Shelf Sci 80:225-234

Leth OK, Dahl K, Peltonen H et al (2013) Sectoral impact assessments for the Baltic Sea region-climate change impacts on biodiversity, fisheries, coastal infrastructure and tourism. Coastline Reports 21. EUCC - Die Küsten Union deutschland e. V. c/o Leibniz-Institut für Ostseeforschung Warnemünde, Rostock, Germany, p 132

Ljungberg R, Pikkarainen A, Lehtiniemi M et al (2011) Vieraslajien havaitseminen Suomen merialueen seurannoissa. Suomen ympäristö. Finnish Environment Institute, Helsinki, p 68

Luther A (1950) Om Balanus improvisus i Östersjön. Acta Societatis pro Fauna et Flora Fennica 45:155-160

Marelli DC, Gray S (1983) Conchological redescriptions of Mytilopsis sallei and Mytilopsis leucophaeata of the brackish western Atlantic. Veliger 25:185-193

Marty J (2008) Biological synopsis of the bloody red shrimp (Hemimysis anomala). Canadian manuscript report of Fisheries and Aquatic Sciences, XXXX vii:36

Maximov A (2011) Large-scale invasion of Marenzelleria spp. (Polychaeta; Spionidae) in the eastern Gulf of Finland, Baltic Sea. Russ J Biol Invasions 2:11-19

Maximov AA, Eremine TR, Lange EK et al (2014) Regime shift in the ecosystem of the eastern Gulf of Finland caused by the invasion of the polychaete Marenzelleria arctia. Oceanology 54:46-53

Maximov A, Bonsdorff E, Eremina T et al (2015) Contextdependent consequences of Marenzelleria spp. (Spionidae: Polychaeta) invasion for nutrient cycling in the Northern Baltic Sea. Oceanologia 57:342-348

McDowell WG, Benson AJ, Byers JE (2014) Climate controls the distribution of a widespread invasive species: implications for future range expansion. Freshw Biol 59:847-857

Meier HEM (2001) On the parameterization of mixing in threedimensional Baltic Sea models. J Geophys Res Oceans 106:30997-31016

Meier HEM (2007) Modeling the pathways and ages of inflowing salt- and freshwater in the Baltic Sea. Estuar Coast Shelf Sci 74:610-627

Meier HEM, Kauker F (2003) Modeling decadal variability of the Baltic Sea: 2. Role of freshwater inflow and large-scale atmospheric circulation for salinity. J Geophys Res Oceans 108:3368

Meier HEM, Kjellström E, Graham LP (2006) Estimating uncertainties of projected Baltic Sea salinity in the late 21st century. Geophys Res Lett 33:L15705

Meier HEM, Höglund A, Döscher R et al (2011) Quality assessment of atmospheric surface fields over the Baltic Sea from an ensemble of regional climate model simulations with respect to ocean dynamics. Oceanologia 53:193-227

Meier HEM, Hordoir R, Andersson HC et al (2012) Modeling the combined impact of changing climate and changing nutrient loads on the Baltic Sea environment in an ensemble of transient simulations for 1961-2099. Clim Dyn 39:2421-2441
Moore HB, Frue AC (1959) The settlement and growth of Balanus improvisus, B. eburneus and B. amphitrite in the Miami area. Bull Mar Sci 9:421-440

Nakicenovic N, Alcamo J, Davis G et al (2000) Emission scenarios. A special report of working group III of the Intergovernmental Panel on Climate Change. Cambridge University Press, Cambridge

Neumann T, Eilola K, Gustafsson BG et al (2012) Extremes of temperature, oxygen and blooms in the Baltic Sea in a changing climate. Ambio 41:574-585

Nicol EAT (1936) The brackish-water lochs of North Uist. Proc R Soc Edinb B Biol Sci 56:169-195

Norkko J, Reed DC, Timmermann Ket al (2012) A welcome can of worms? Hypoxia mitigation by and invasive species. Glob Change Biol 18:422-434

Ojaveer H, Kotta J (2014) Ecosystem impacts of the widespread non-indigenous species in the Baltic Sea: literature survey evidences major limitations in knowledge. Hydrobiologia 750:171-185

Ojaveer H, Simm M, Lankov A et al (2000) Consequences of invasion of a predatory cladoceran. ICES C.M. 2000/U:16

Ojaveer H, Jaanus A, MacKenzie BR et al (2010) Status of biodiversity in the Baltic Sea. PLoS ONE 5:1-19

Ojaveer H, Kotta J, Põllumäe A et al (2011) Alien species in a brackish water temperate ecosystem: annual-scale dynamics in response to environmental variability. Environ Res 111:933-942

Olenin S, Orlova MI, Minchin D (1999) Dreissena polymorpha (Pallas, 1771). In: Gollasch S, Minchin D, Rosenthal H, Voigt M (eds) Case histories on introduced species: their general biology, distribution, range expansion and impact. Logos, Berlin, pp 37-42

Olenin S, Narščius A, Minchin D et al (2014) Making nonindigenous species information systems practical for management and useful for research: an aquatic perspective. Biol Conserv 173:98-107

Omstedt A, Edman M, Claremar B et al (2012) Future changes in the Baltic Sea acid-base $(\mathrm{pH})$ and oxygen balances. Tellus B 64

Orlova MI, Telesh IV, Berezina NA et al (2006) Effects of nonindigenous species on diversity and community functioning in the eastern Gulf of Finland (Baltic Sea). Helgol Mar Res 60:98-105

Panov VE, Alimov AF, Golubkov SM et al (2002) Environmental problems and challenges in the Neva estuary (eastern Gulf of Finland). In: Schernewski G, Schiewer U (eds) Baltic coastal ecosystems. Springer, Berlin, pp 171-184

Panov V, Rodionova N, Bolshagin P et al (2007) Invasion biology of Ponto-Caspian onychopod cladocerans (Crustacea: Cladocera: Onychopoda). Hydrobiologia 590:3-14

Parmesan C (2006) Ecological and Evolutionary Responses to Recent Climate Change. Annu Rev Ecol Evol Syst 37:637-669

Pinkster S, Smit H, Brandse-de Jong N (1977) The introduction of the alien amphipod Gammarus tigrinus Sexton, 1939, in the Neatherlands and it's competition with indigenous species. Crustaceana Supplement 4:91-105

Qian H, Ricklefs RE (2006) The role of exotic species in homogenizing the North American flora. Ecol Lett 9:1293-1298 
Remane A (1934) Die Brachwasserfauna. Zoologischer Anzeiger 7:34-74

Reuschel S, Cuesta JA, Schubart CD (2010) Marine biogeographic boundaries and human introduction along the European coast revealed by phylogeography of the prawn Palaemon elegans. Mol Phylogenet Evol 55:765-775

Rivier IK (1998) The predatory Cladocera (Onychopoda: Podonidae, Polyphemidae, Cercopagidae) and Leptodorida of the world. Backhyus, Leiden

Rockström J, Steffen W, Noone K et al (2009) A safe operating space for humanity. Nature 461:472-475

Salemaa H, Hietalahti V (1993) Hemimysis anomala G.O. Sars (Crustacea: Mysidacea) - immigration of a Ponto-Caspian mysid into the Baltic Sea. Ann Zool Fenn 30:271-276

Sareyka J, Kraufvelin P, Lenz M et al (2011) Differences in stress tolerance and brood size between a non-indigenous and an indigenous gammarid in the northern Baltic Sea. Mar Biol 158:2001-2008

Segerstråle SG (1957) Baltic Sea. In: Hedgpeth JW (ed) Treatise on marine ecology and paleoecology. Geological Society of America, New York, pp 751-800

Simm M, Ojaveer H (2006) Taxonomic status and reproduction dynamics of the non-indigenous Cercopagis in the Gulf of Riga (Baltic Sea). Hydrobiologia 554:147-154

Somero GN (2012) The physiology of global change: linking patterns to mechanisms. Annu Rev Mar Sci 4:39-61

Sopanen S (2008) The effect of temperature on the development and hatching of resting eggs of non-indigenous predatory cladoceran Cercopagis pengoi in the Gulf of Finland, Baltic Sea. Mar Biol 154:99-108

Sorte CJB, Williams SL, Zerebecki RA (2010) Ocean warming increases threat of invasive species in a marine fouling community. Ecology 91:2198-2204

Southward AJ (1957) On the behaviour of barnacles III. Further observations on the influence of temperature and age on cirral activity. J Mar Biol Assoc UK 36:323-334

Stanczykowska A (1977) Ecology of Dreissena polymorpha (Pal.) (Bivalvia) in lakes. Pol Arch Hydrobiol 24:531-545

Surowiec J, Dobrzycka-Krahel A (2008) New data on the nonindigenous gammarids in the Vistula Delta and the Vistula Lagoon. Oceanologia 50:443-447

Taylor PM, Harris RR (1986) Osmoregulation in Corophium curvispinum (Crustacea: Amphipoda), a recent coloniser of freshwater. II. Water balance and the functional anatomy of the antennary organ. J Comp Physiol B 156:331-337

Thuiller W, Richardson DM, Midgley GF (2007) Will climate chage promote alien invasions? In: Nentwig W (ed) Biological invasions. Springer, Berlin, pp 197-211

Turoboyski K (1973) Biology and ecology of the crab Rhithropanopeus harrisii ssp. tridentatus. Mar Biol 23:303-313

Tyrrell T, Schneider B, Charalampopoulou A et al (2008) Coccolithophores and calcite saturation state in the Baltic and Black Seas. Biogeosciences 5:485-494

UNEP (2006) Marine and coastal ecosystems and human wellbeing: A synthesis report based on the findings of the Millenium Ecosystem Assessment. UNEP, pp. 76

Verween A, Vincx M, Degraer S (2010) Mytilopsis leucophaeata: The brackish water equivalent of Dreissena polymorpha? A review. In: van der Velde G, Rajagopal S, bij de Vaate A (eds) The zebra mussel in Europe. Backhuys, Leiden, pp 29-44

Viitasalo-Frösén S, Laine AO, Lehtiniemi M (2009) Habitat modification mediated by motile surface stirrers versus semi-motile burrowers: potential for a positive feedback mechanism in a eutrophicated ecosystem. Mar Ecol Prog Ser 376:21-32

Vuorinen I, Hänninen J, Rajasilta M et al (2015) Scenario simulations of future salinity and ecological consequences in the Baltic Sea and adjacent North Sea areas-implications for environmental monitoring. Ecol Ind 50:196-205

Wallace C (1992) Parthenogenesis, sex and chromosomes in Potamopyrgus. J Molluscan Stud 58:93-107

Walther G-R, Roques A, Hulme PE et al (2009) Alien species in a warmer world: risks and opportunities. Trends Ecol Evol 24:686-693

Whittier T, Herlihy A, Pierson S (1995) Regional susceptibility of northeast lakes to zebra mussel invasion. Fisheries 20:20-27

Wijnhoven S, van Riel MC, van der Velde G (2003) Exotic and indigenous freshwater gammarid species: physiological tolerance to water temperature in relation to ionic content of the water. Aquat Ecol 37:151-158

Zaiko A, Lehtiniemi M, Narščius A et al (2011) Assessment of bioinvasion impacts on a regional scale: a comparative approach. Biol Invasions 13:1739-1765 